\title{
BAKTERI RESISTEN MERKURI PADA ALGA COKLAT Padina australis DARI PERAIRAN KIMA BAJO SULAWESI UTARA
}

\author{
(MERCURY RESISTANT BACTERIA, IN BROWN ALGAE Padina australis \\ FROM KIMA BAJO WATERS OF NORTH SULAWESI)
}

\section{Sri Winisari Van Gobel ${ }^{1}$, Desy M. H. Mantiri ${ }^{\star}$, James J. H. Paulus ${ }^{1}$, Rizald M. Rompas ${ }^{1}$, Natalie D. Rumampuk ${ }^{1}$, Sammy N. J. Longdong ${ }^{2}$}

1. Mahasiswa Program Studi IImu Kelautan, FPIK UNSRAT Manado

2. Staf Pengajar Program Studi IImu Kelautan FPIK UNSRAT Manado

3. Staf Pengajar Program Studi Budidaya Perairan, FPIK UNSRAT Manado

Corresponding author: dmh mantiri@unsrat.ac.id

\begin{abstract}
ABSTRACK
Padina australis is a species of brown algae from the Phaeophyta division which is generally distributed in marine waters. This species is able to survive in waters that have low water quality. The purpose of this study was to isolate mercury-resistant bacteria in P. australis, to determine the shape of the cells and the characteristics of the bacteria. The method used was conventional bacterial isolation and tested on mercury chloride compounds $\left(\mathrm{HgCl}_{2}\right)$. The results of the bacterial morphology test of the $\mathrm{P}$. australis algae were Gram positive in the form of monobacilli and streptobacilli and had the ability to be resistant to mercury at concentrations of 250,500 and $1000 \mathrm{ppm}$. The antibiotic test of the mercury-resistant bacteria was carried out against amoxicillin, cefixime and doxycycline antibiotics. The results showed that the antibiotic amoxicillin had an inhibition zone of $0.4 \mathrm{~mm}$, the antibiotic cefixime with an inhibition zone of 0.1 $\mathrm{mm}$. and doxycycline had the highest inhibition zone of $1.8 \mathrm{~mm}$, it was seen that bacteria could reduce the effectiveness of a drug.
\end{abstract}

Keywords: Brown algae, Gram positive bacteria, mercury resistant bacteria, antibiotics

\section{ABSTRAK}

Alga laut jenis Padina australis merupakan spesies alga coklat divisi Phaeophyta (alga cokelat) yang umumnya tersebar di perairan laut. Spesies ini mampu bertahan hidup di perairan yang mempunyai kualitas air rendah. Tujuan penelitian ini adalah untuk mengisolasi bakteri resisten merkuri pada alga $P$. australis, mengetahui bentuk sel dan karakteristik bakteri. Metode yang digunakan adalah isolasi bakteri secara konvensional dan diuji pada senyawa merkuri klorida $\left(\mathrm{HgCl}_{2}\right.$.) Hasil uji morfologi bakteri dari alga P. australis adalah Gram positif berbentuk monobasil dan streptobasil serta mempunyai kemampuan resisten terhadap merkuri pada konsentrasi 250, 500 dan 1000 ppm. Uji antibiotik dari bakteri resisten merkuri tersebut dilakukan terhadap antibiotik amoxicillin, cefixime dan doxycycline. Hasil menunjukan bahwa antibiotik amoxicillin mempunyai zona hambat $0,4 \mathrm{~mm}$, antibiotik cefixime dengan zona hambat $0,1 \mathrm{~mm}$. dan doxycycline mempunyai zona hambat tertinggi yaitu $1,8 \mathrm{~mm}$, terlihat bahwa bakteri dapat mengurangi efektifitas suatu obat.

Kata Kunci : Alga coklat, bakteri Gram positif, bakteri resisten merkuri, antibiotik 


\section{PENDAHULUAN}

Padina australis merupakan makroalga dari kelas Phaeophyceae (alga coklat) yang banyak tumbuh dan tersebar di perairan Indonesia termasuk di perairan Kima bajo. Di Sulawesi Utara, alga $P$. australis ditemukan hidup di perairan pesisir Tongkaina (Kepel et al., 2018a), Blongko (Kepel et al., 2018b), Kora-kora (Kepel dan Mantiri, 2019), zona intertidal Pulau Mantehage (Kepel et al., 2019a), Semenajung Minahasa pada musim penghujan (Kepel et al., 2019b), Semenajung Minahasa pada musim kemarau (Kepel et al., 2020), dan perairan pesisir pada beberapa konsentrasi logam berat di Semenajung Minahasa (Tombokan et al., 2020).

Alga ini memiliki bentuk lembaran yang lebar berwarna coklat transparan, dikarenakan di dalam thalusnya terkandung pigmen xantofil, yaitu fukosantin dan klorofil yang terdapat di dalam plastida (Sergiama, 2009). Hidup melekat pada substrat keras di dasar perairan. Menurut (Nontji, 1993), ciriciri $P$. australis adalah thallus berbentuk seperti kipas, membentuk segmen lembaran tipis, warna cokelat kekuningan bagian atas lobus agak melebar dan Holfast berbentuk cakram kecil berserabut (Gambar 1).

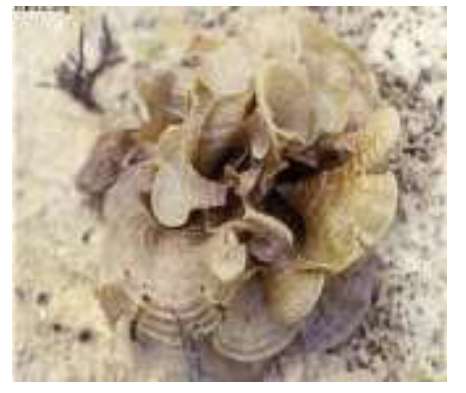

\section{Gambar 1. Padina australis}

Hasil penelitian (Mantiri et al., 2019), pada thallus alga $P$. australis yang hidup di perairan Teluk Totok telah terdeteksi logam berat seperti arsen, kadmium, timbal dan merkuri. Proses transfer logam ke alga, antara lain berasal dari sedimen dimana alga-alga tersebut hidup. Walaupun kadar logam berat dalam perairan relatif rendah terutama pada sedimen, namun dapat diabsorbsi dan terakumulasi secara biologis oleh organisme termasuk alga laut (Darmono, 1995).

Alga mampu menyerap logam berat melalui sistem biologi biosorption (Utomo et al., 2016). Hidayat et al., (2021) dalam penelitian budidaya alga $P$. australis di perairan Kima Bajo, menemukan beberapa logam pada thallus alga, namun alga tersebut tetap tumbuh dengan baik. Alga juga merupakan fitoremediator yang baik di perairan. Untuk itu perlu diteliti faktor penunjang apa yang ada pada alga sehingga dapat bertahan hidup pada kondisi kualitas air rendah. Pantouw et al., (2018) menemukan lima genus bakteri resisten logam arsen pada sedimen di pesisir Teluk Buyat. Oleh karena itu penelitian ini dilakukan untuk mengetahui apakah terdapat bakteri resisten logam merkuri $\left(\mathrm{HgCl}_{2}\right)$ pada thallus alga $P$. australis yang hidup di perairan Kima Bajo.

\section{METODE PENELITIAN}

\section{Lokasi penelitian}

Lokasi pengambilan sampel alga $P$. australis dilakukan di perairan Kima Bajo Kecamatan Wori Minahasa Utara (Gambar 2).

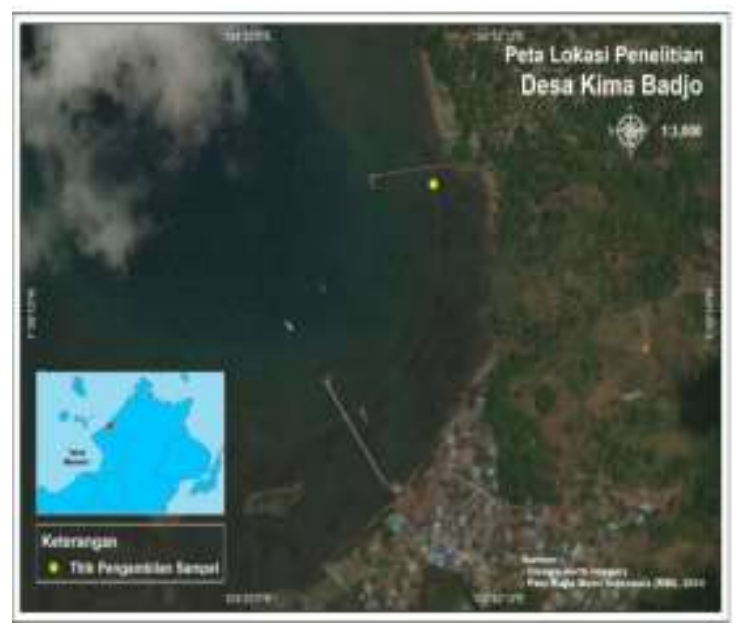

Gambar 2. Peta Lokasi Penelitian 
Perairan ini berdekatan dengan pemukiman dan berjarak sekitar $2 \mathrm{~km}$ dari Muara Sungai Talawaan Bajo. Penelitian dilaksanakan pada bulan April 2021. Pengambilan sampel alga dilakukan dengan metode survei jelajah.

Alga diambil secara langsung dengan tangan dan diidentifikasi merujuk kepada buku Trono (1997). Selanjutnya sampel langsung dibawa dengan cool box ke laboratorium untuk dilakukan pengujian bakteri resisten merkuri dan uji morfologi bakteri. Pengujian tersebut dilakukan di Laboratorium Farmasi Fakultas Matematika dan Ilmu Pengetahuan Alam Universitas Sam Ratulangi.

\section{Isolasi Sampel}

Sampel Alga dipotong kecil dengan ukuran $2 \mathrm{~cm}$, masing-masing diambil 3 potongan alga dimasukkan ke dalam medium biakan (Media NA) yang sudah diberi perlakuan merkuri klorida $\left(\mathrm{HgCl}_{2}\right)$ dengan konsentrasi 250, 500 dan 1000 ppm, selanjutnya di-inkubasi pada suhu $37^{\circ} \mathrm{C}$ selama 24 jam. Dilakukan pengamatan pertumbuhan koloni bakteri dan menghitung jumlah koloni yang tumbuh.

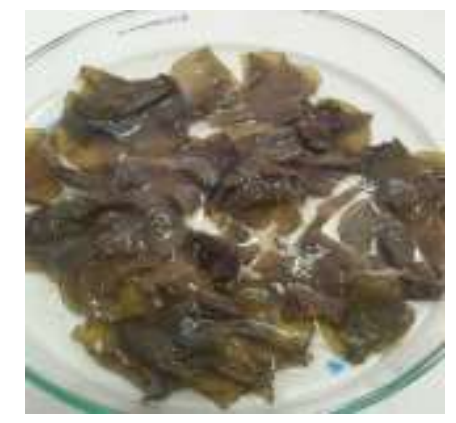

Gambar 3. Sampel alga $P$. Australis

Selanjutnya diambil satu koloni bakteri pada konsentrasi berbeda dan menginokulasikan lagi pada media NA dalam cawan petri dengan metode goresan $\mathrm{T}$ (3 kuadran), inkubasi kembali selama 1 x 24 jam. Dilakukan juga pengamatan pertumbuhan koloni.

Cuplikan koloni bakteri yang tumbuh pada media NA diambil dengan jarum ose, untuk dibuat biakan murni, kemudian diinokulasi pada media agar miring secara zig-zag, lalu dilakukan inkubasi selama $1 \mathrm{x}$ 24 jam. Bakteri yang tumbuh pada media agar miring diambil untuk pengujian lanjut.

\section{Uji Morfologi}

Uji morfologi bakteri dilakukan dengan metode pewarnaan gram. bertujuan untuk menentukan karateristik mikroskopik isolat uji dan reaksinya terhadap pewarnaan gram serta bentuk sel dan ukurannya.

\section{Uji resisten antibiotik terhadap bakteri resisten merkuri}

Uji resisten antibiotik dilakukan dengan menginokulasi bakteri resisten merkuri pada media seleksi padat Nutrien Agar. Kertas disk antibiotik dengan konsentrasi standar beberapa jenis antibiotik seperti amoxicillin, cefixime dan doxycycline diletakan menggunakan pinset steril pada permukaan media yang sudah diinokulasikan bakteri resisten merkuri. Kertas disk antibiotik diatur jaraknya agar tidak terlalu rapat lalu diinkubasi selama 1x24 jam. Diamati perubahan yang terjadi dan diukur zona beningnya dengan menggunakan penggaris (cm) (Dwyana,2012)

\section{HASIL DAN PEMBAHASAN}

\section{Pengamatan Isolat bakteri yang tumbuh pada variasi konsentrasi $\mathrm{HgCl}_{2}$.}

Kehadiran bakteri resisten merkuri di suatu perairan, memainkan peranan yang sangat penting dalam mereduksi kandungan logam toksik berbahaya serta menghambat terbentuknya logam organik (Rombke dan Moltmann, 1996).

Pengamatan bakteri setelah diinkubasi selama $1 \times 24$ jam terjadi pertumbuhan koloni bakteri pada media agar yang mengandung $\mathrm{HgCl}_{2}$ dengan variasi konsentrasi merkuri mulai dari 250, 500 dan 1000 ppm (Gambar 4). Hasil ini menunjukan bahwa bakteri dari sampel 
alga, mampu tumbuh pada media NA dan merupakan bakteri resisten terhadap $\mathrm{HgCl}_{2}$. Selanjutnya dipilih konsentrasi tertinggi yaitu 500 dan 1000 ppm untuk diinkubasi selama 1x24 pada media seleksi.

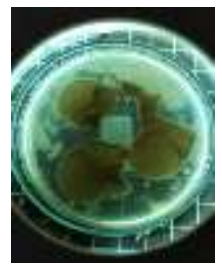

a

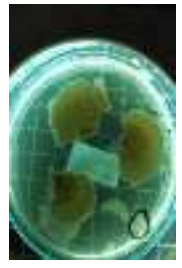

b

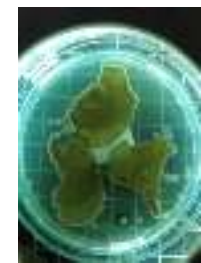

c
Gambar 4. Pertumbuhan bakteri pada media padat dengan variasi konsentrasi merkuri

a. Konsentrasi $\mathrm{HgCl}_{2} 250 \mathrm{ppm}$

b. Konsentrasi $\mathrm{HgCl}_{2} 500 \mathrm{ppm}$

c. Konsentrasi $\mathrm{HgCl}_{2} 1000$ ppm

Bakteri resisten merkuri pada alga $P$. australis bisa juga merupakan bakteri simbion dari alga. Bakteri resisten merkuri, memiliki gen yang resisten (Noviani dan Gusrizal, 2004). Beberapa jenis bakteri dapat mendektosifikasi logam berat seperti merkuri. Proses detoksifikasi merkuri oleh bakteri resisten merkuri terjadi karena bakteri resisten merkuri memiliki gen resisten merkuri, yaitu mer operon. Struktur mer operon berbeda untuk tiap jenis bakteri (Mann, 2009), dimana mengubah $\mathrm{Hg}^{2+}$ menjadi $\mathrm{Hg}^{0}$. Umumnya struktur mer operon terdiri dari gen metaloregulator (merR), gen transpor merkuri (merT, merP, merC), gen merkuri reduktase (merA) dan organo merkuri liase (merB). (Nascimento \& Souza, 2003).

Kondisi toksik lingkungan perairan merupakan suasana lingkungan yang baik dalam memainkan peran sebagai bakteri pereduksi logam merkuri di perairan (Zakrzewski, 1997)., Sebaliknya pada kondisi hypoxia, beberapa bakteri seperti dari deltaproteobacter, akan memainkan peranan yang dapat berakibat buruk bagi organisme (Capo et al., 2020). Kesetimbangan lingkungan perairan dari beberapa reaksi reduksi dan oksidasi serta pengruaian bahan organik banyak berkaitan erat dengan situasi ini (Parks et al, 2018)

\section{Kemampuan bakteri tumbuh pada media dengan variasi konsentrasi merkuri}

Konsentrasi tertinggi yaitu 500 dan 1000 ppm dipilih untuk dilakukan diinkubasi selama 1x24 pada media seleksi.

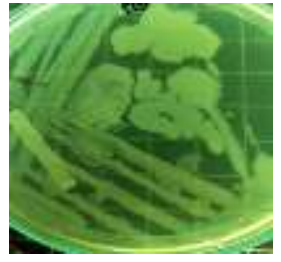

(a) $\mathrm{HgCl}_{2} 500$ ppm

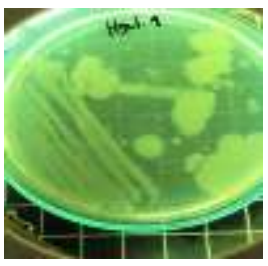

(b) $\mathrm{HgCl}_{2} 1000$ ppm
Gambar 5. pertumbuhan bakteri pada media seleksi padat dengan variasi konsentrasi merkuri

Pada gambar 5 terlihat pertumbuhan bakteri, namun koloni yang terbentuk jumlahnya berbeda pada setiap konsentrasi merkuri yang diberikan. Semakin tinggi konsentrasi merkuri, bakteri yang tumbuh semakin sedikit.

\section{Pengamatan bakteri resisten merkuri dengan metode pewarnaan gram}

Hasil pengamatan pada kedua sampel dengan konsentrasi $\mathrm{HgCl}_{2} 500$ ppm dan 1000 ppm, menunjukkan warna yang sama yaitu berwarna ungu, merupakan bakteri Gram positif.

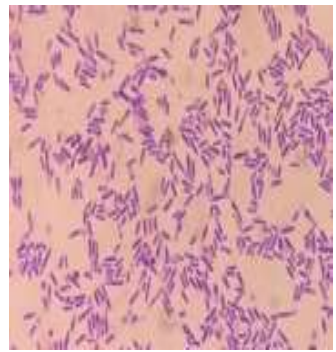

(a). $500 \mathrm{ppm}$

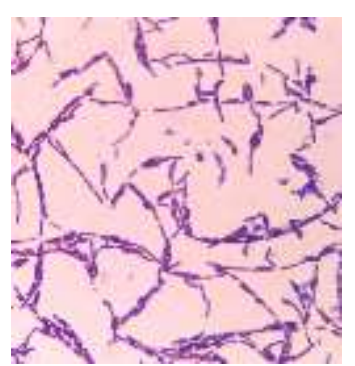

(b). $1000 \mathrm{ppm}$
Gambar 6. Morfologi Bakteri

Bakteri ini adalah bakteri yang memiliki membran tunggal yang dilapisi 
peptidoglikan tebal. Bentuk sel bakteri tersebut yaitu monobasil (gambar 6.a) dan streptobasil (gambar 6.b). Hasil uji morfologi yang dibandingkan dengan buku Bergey's Determinative Bacteriology (Holt et al.,1994) didapatkan kecocokan karakteristik pada jenis bakteri Bacillus sp. Dimana memiliki sel berbentuk batang dan lurus serta sering tersusun secara berpasangan atau tunggal dengan ujung yang berbentuk bulat atau bersegi. Bacillus $s p$. termasuk bakteri gram positif, memiliki endospora yang berbentuk oval atau bundar atau silinder dan Bacillus sp. Merupakan bakteri aerob yang mampu bertahan hidup pada kondisi yang buruk.

\section{Pengamatan Uji Antibiotik}

Uji antibiotik digunakan untuk menguji kepekaan bakteri resisten merkuri pada konsentrasi 500 dan 1000 ppm terhadap beberapa antibiotik.

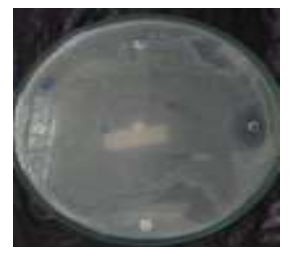

a

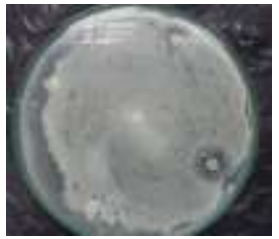

b
Gambar 7. Uji Antibiotik pada $\mathrm{HgCl}_{2} 500$ ppm (a)dan 1000 ppm (b)

Pengujian ini menunjukkan bahwa antibiotik amoxicillin mempunyai zona hambat 0,4 $\mathrm{mm}$, antibiotik cefixime dengan zona hambat $0,1 \mathrm{~mm}$. sedangkan pada uji antibiotik doxycycline mempunyai zona hambat tertinggi yaitu $1,8 \mathrm{~mm}$. Antibiotik doxycycline aktif melawan bakteri karena lebih hidrofilik sehingga mampu menembus pori dinding bakteri. Sedangkan pada amoxicillin dan cefixime memiliki sifat atau kemampuan untuk menahan efek antibiotik . Hal ini menunjukkan bahwa bakteri dapat merubah diri sedemikian rupa sehingga dapat mengurangi efektifitas suatu obat, bahan kimia ataupun zat lain (Dwyana, 2012).

\section{KESIMPULAN}

Berdasarkan penelitian yang dilakukan, maka dapat disimpulkan;

1. Bakteri pada alga Padina australis merupakan bakteri resisten merkuri dan mampu bertahan hidup pada variasi konsentrasi $\mathrm{HgCl}_{2}$ yaitu 250, 500 dan 1000 ppm. Semakin tinggi konsentrasi merkuri, pertumbuhan koloni semakin berkurang.

2. Pengamatan morfologi menunjukan Bakteri Gram Positif (warna ungu), dengan bentuk monobasil dan streptobasil.

3. Pada uji antibiotik, bakteri resisten merkuri juga resisten terhadap antibiotik amoxicillin dan cefixime tetapi bakteri resisten merkuri sensitif terhadap antibiotik doxycycline.

\section{DAFTAR PUSTAKA}

Dwyana, S. dan Fahruddin. 2012. Uji Resistensi Antibiotik pada Bakteri Resisten Merkuri $(\mathrm{Hg})$ yang Diisolasi dari Kawasan Pantai Losari Makassar. Sainsmat. Vol 1. No.2. Hal 199-204

Capo E., Soerensen A.L., Bravo A.G., Bertilson S. 2020. Deltaproteobacteria and Spirochaetes-Like Bacteria Are Abundant Putative Mercury Methylators in Oxygen-Deficient Water and Marine Particles in the Baltic Sea. Front. Microbiol., 22 September 2020

Darmono, 1995, Logam Dalam Sistem Biologi Makhluk hidup, 111, 131-134, Universitas Indonesia Press, Jakarta.

Hidayat, S, Mantiri, Desy M.H., Paulus, James J.H., Lasut, Markus T., Rumampuk, Natalie D.C., Undap, Suzanne, Sumilat Deiske A. 2021. Accumulation of heavy metals (As, Cd, $\mathrm{Pb}, \mathrm{Hg}$ ) on brown algae, Padina australis, cultivated in Kima Bajo Waters, North Minahasa Regency. Aquatic sains and management. Vol. 9. No.1. (2021) 
Holt, J.G and Krieg, N.R. 2000. Bergey's Manual Of Determinative Bacteriology. $9^{\text {th }}$ Edition Lippincott Williams and Wilkins. A Wolters Kluwer Company . Philadelphia. USA.

Kepel, R. C., Mantiri, D. M. H. 2019. Biodiversitas makroalga di perairan pesisir Kora-Kora, Kecamatan Lembean Timur, Kabupaten Minahasa. Jurnal IImiah Platax 7(2): 49-59.

Kepel, R. C., Mantiri, D. M. H., Nasprianto, 2018a. Biodiversitas makroalga di perairan pesisir Tongkaina, Kota Manado. Jurnal IImiah Platax 6(1): 160173.

Kepel, R. C., Mantiri, D. M. H., Rumengan, A., Nasprianto, 2018b. Biodiversitas makroalga di perairan pesisir Desa Blongko, Kecamatan Sinonsayang, Kabupaten Minahasa Selatan. Jurnal IImiah Platax 6(1): 174-187.

Kepel, R. C., Lumingas, L. J. L., Watung, P. M. M., Mantiri, D. M. H. 2019a. Community structure of seaweeds along the intertidal zone of Mantehage Island, North Sulawesi, Indonesia. AACL Bioflux, 12(1): 87-101.

Kepel, R. C., Lumingas, L. J. L., Tombokan, J. L., Mantiri, D. M. H. 2019b. Biodiversity and community structure of seaweeds in Minahasa Peninsula, North Sulawesi, Indonesia. AACL Bioflux, 12(3): 880-892.

Kepel, R. C., Lumingas, L. J. L., Tombokan, J. L., Mantiri, D. M. H. 2020. Community structure of seaweeds in dry season in Minahasa Peninsula, North Sulawesi, Indonesia. AACL Bioflux, 13(1): 392-402.

Mann, Jeffrey, E. 2009. Recent advance in the development of Deinococcus sp for use in bioremediation of mixed radioaktive waste Basic Biotechnology. 5: 60-65

Mantiri, D. M. H., Kepel, R. C., Manoppo, H., Paulus, J. J. H., Paransa, D. S. 2019. Nasprianto Metals in seawater, sediment and Padina australis (Hauck, 1887) algae in the waters of North Sulawesi. AACL Bioflux, 12(3): 840850.
Nascimento, A.M.A., and Chartone-Souza, E. 2003. Operon mer : Bacterial Resistance To Mercury and Potential for Bioremediation of Contaminated Enviroments. Genetics and Molecular Research 2 (1) : 92-101

Nontji, A. 1993. Laut Nusantara Cetakan kedua. Djambatan. Jakarta.

Noviani, R. dan Gusrizal. 2004. Bakteri Resisten Merkuri Spektrum Sempit dari Daerah Bekas Penambangan Emas Tanpa Izin (PETI) Mandor, Kalimantan Barat. [Skripsi] Jurusaan Kimia, FMIPA, Universitas Tanjungpura.

Parks D.H., Maria C., Waite D., Rinke C., Skarshewski., Chaumeil P.A., Philip H., 2018. A standardized bacterial taxonomy based on genome phylogeny substantially revises the tree of life. Nat Biotechnol. $2018 \quad$ Nov;36(10):9961004. doi: $\quad 10.1038 / n b t .4229$. Epub 2018 Aug 27

Pantow, Natalia M. Kepel, Billy J. Fatimawali. 2018. Isolasi dan Identifikasi Bakteri Resisten Arsen pada Sedimen di Pesisir Laut Buyat Tahun 2018. Jurnal e-Biomedik (eBm), Volume 6, Nomor 2, Juli-Desember 2018

Rombke J. and Moltmann, J.F. 1996. Apllied Ecotoxicology. Lewis Publishers. Boca Raton.

Sergiama. 2009. Alga Hijau Biru. Agro Media Pustaka. Jakarta.

Tombokan, J. L., Kepel, R. C., Mantiri, D. M. H., Paulus, J. J. H., Lumingas, L. J. L., 2020. Comparison of seaweed communities in coastal waters with different heavy metals concentrations in Minahasa Peninsula, North Sulawesi, Indonesia. AACL Bioflux, 13(4): 17791794.

Trono, G. C. 1997. Field Guide and Atlas of the Seaweed Recources of the Philippines. Bookmarks, Inc. Makaty City. 306 hal.

Utomo, H. D., Tan, K. X. D., Choong, Z. Y. D., Yu, J. J., Ong, J. J., Lim, Z. B. 2016. Biosorption of Heavy Metal by Algae Biomass in Surfase Water. Scientific 
Research Publishing. Vol. 7. No. 11. 14 Hal.

Zakrzewski A.F. 1997. Principles Of Environmental Toxicology. ACS Monograp 190. American Chemicals Society, Washington DC. 